many places it looks like a miniature plantation, and is a serious detriment to the pasture. Ir an equal degree the elms have exhibited the same tendency to throw up an infinite number of shoots, and I am curious to know whether I am right in considering it to be due to the great heat of the surface of the soil.

C. J. ROBINSON

\section{A Natural Fernery}

NEAR where I am writing, in this parish (East Woodhay) is a deep hollow lane, with high sloping banks, which are abundantly clothed with the following ferns (nomenclature and arrangement from Dr. Hooker's new "Flora") :-Pteris aquilina, Lomaria spicant (rare), Asplenium Adiantum-nigrum, A. filixfomina, Scolopendrium vulgare, Aspidium aculeatum, $A$. angulare, Nephrodizm filix-mas (with several pretty barren varieties), and Polypodium vulgare. Although the ferns are of the most common species, yet from the sloping nature of the ground, and the intermixing of a few other plants, such as Equisetum sylvaticum, Lactuca muralis (very fine), Digitalis purpurea, Cambanula Trachelium, Hypericum pulchrum, Funcus glaucus and compressus, with a few pretty Rose and Rubi, tend to make it the most charming bit of fern scenery that $I$ have ever fallen in with.

\section{HENRY REEKS}

\section{The Science and Art Department}

In your impression of the $4^{\text {th }}$ you have touched upon a point which has of late interested me much, viz, the science teaching of the "Science and Art Department."

At the commencement of the article you say that the work done is so little known that you have ventured its history. If you will allow me a small portion of your valuable space, I will put before your readers a few facts concerning the said "Department."

The teachers in the employ of the Department have no fixed salary; payments are made upon results to those persons who have passed in the first or second class (advanced stage) in the subject or subjects in which they give instruction, or who have passed in "Honours."

Now, a teacher's certificate is by no means difficult to obtain (advanced stage), provided Honours are not tried for, and consequently there is a large number of low-class teachers in the ranks, or those who are only grounded in elements of the subject which they are certificated to teach. For instance, a pupil on entering in 1869 for the examination and taking a second class in the advanced stage is entitled to teach and earn payments on results; such a teacher may only be grounded in the elements of the subject (say chemistry), and when he is applied to for the solution of a problem governed by physical laws he is at a loss and the pupil gets no answer to his query. It is my opinion that the teachers' examinations are much too easy. I think a certificate ought not to be granted unless the candidate has shown that he is familiar with the subject he intends to teach, and also with the cognate sciences. A chemistry teacher should know, at least, light and heat, magnetism and electricity; but at present such knowledge is not required.

I am not speaking specially for chemistry; geometry I may instance. There are many teachers at present engaged in giving instruction who know not a jot of Euclid's elements, nor can they work out the simplest algebraical problem. Should not a teacher know the theory as well as the practice, so as to give"a definite and true answer to a pupil's inquiries. Machine drawing is the same ; the examination consists of mere copying, and I can safely say that there are many teachers of mechanical drawing who would not be able to answer a single question of the paper set by the Society of Arts' examiner.

Science-teaching is daily becoming more and more appreciated, in some districts, however, only but very slowly; and I think it is only right that those teachers who do take an interest in science should endeavour to keep up the standard of the teacher. I should like to see every teacher obliged to pass in Honours-then the chemist would not pass without a thorough knowledge of physics, neither would the teacher of plane and solid geometry escape so easily, nor the pseudo-machinist obtain a certificate in a subject he was not competent to teach. But we must look at science as no.w taught from another point of view. It is for the encouragement of science among artisans (designated in the Science Directory as "the industrial classes") that the payments are made to teachers, the teachers not being able to claim any sum upon those which do not strictly come under that denomination.

Now, in the branch of chemistry some important rules have lately been made: candidates for the advanced stage are to be taught qualitative analysis, and each is to be supplied with a $2 l$. set of apparatus, the artisan cannot afford to supply it himself; the institution, or other place where the class meets, has only just enough funds to enable it to keep its head above water-who is then to supply it? The teacher ; but often he will not see his way clear, for if he supplies it, 50 per cent. only is allowed him if the candidate obtains a first class. The pecuniary result to a teacher then is-for passing a student in the first class $I l$, and in the second a loss of $\mathrm{I} /$., so therefore it will be advantageous for a teacher to keep his pupils out of the advanced stage altogether. If the authorities continue to let the rule stand, I should think payments would be allowed on middle-class students, as they are the only ones who probably could provide them with the apparatus.

It is all very well to say that an artisan, if he take sufficient interest in the science, will provide himself with the apparatus, but it generally happens that the willing ones are those who have the least opportunity of doing what they wish.

The past session has been a trying one for all teachers, for not only have the payments been reduced, but, to make up the list of evils, the standard has been raised, and consequently fewer have passed. The current session seems to be attended by as many drawbacks, which, if not withdrawn or somewhat modified, will, in the opinion of the majority of teachers, produce injurious results.

\section{An "Honours Certificated Science Teacher"}

\section{The Intended Engineering College}

WILL you allow me a small space in NATURE to call attention to a subject which seems to me to require the serious consideration of everyone who is interested in the progress of science in this country?

In reply to a question put to him in the House of Commons by Mr. Plunket, on the $9^{\text {th }}$ instant, Mr. Grant Duff is reported to have said that it is the intention of Government to establish an engineering college for the Indian service, to be entered by competitive examination. Mr. Grant Duff does not appear to have entered into any detail with regard to the instruction to be given in the intended college, but it is fair to assume that Go. vernment would not think it worth while to take the education of engineers for India into its own hands, except with the inten. tion of giving them a thorough and systematic training, at least as complete as what is already supplied by existing institutions. In this case, the instruction to be given in the new college will embrace at least a three years' course of study devoted to pure and applied mathematics, mechanics, physics, chemistry, geology, and the principles of engineering, in addition to the actual practice in the drawing office and workshop. That is to say, the Government school of engineering will be, on this supposition, what the Government School of Mines has become, in the main, a school of pure science.

Now, in view of this probability, the question suggests itselfwhether it is fair and just that institutions like University College and King's College in London, and Owens College in Manchester, * which, without Government support or help of any kind, offer precisely the lkind of training which we suppose the new college is intended to impart, should have to compete with an institution supported by Government prestige and Government money. The answer to this question affects not merely the interests of private institutions, such as those which have been mentioned, but, so far as the existence of these institutions is a benefit to the general public, it affects the interests of the whole nation; for in the case of colleges which depend for all or much of their income upon the general demand for education, their efficiency and their power to supply teaching of the highest kind, camnot but be seriously interfered with, if they are to be cleprived of all share in the training of a class of pupils numerous enough to induce the Government to found a separate college for them alone. The course which Government proposes to adopt would, it seems to me, be justifiable only if the existing colleges were inefficient, and it had a clear prospect of establishing a more successful institution. As I have the honour to be connected with one of the Colleges in question, I do not intend to discuss their merits further than

* The Universities of Glasgow and Edinburgh might also be referred to although they do receive sume ameunt of aid from the pubic funds. 